\title{
PERILAKU PEMBELIAN SECARA ONLINE GENERASI MILENIAL INDONESIA
}

\author{
Ardik Praharjo \\ Program Studi Manajemen \\ Fakultas Ekonomi dan Bisnis \\ Universitas Muhammadiyah Malang \\ Email : ardikpraharjo@umm.ac.id
}

\begin{abstract}
ABSTRAK
Generasi milenial merupakan generasi yang sangat berpengaruh dalam hal penggunaan internet. Generasi tersebut juga menjadi generasi yang paling banyak dan marak dalam berbelanja secara online. Tujuan pada penelitian ini yaitu untuk mengetahui pengaruh kegunaan, estetika, interaksi, dan bauran pemasaran pada perilaku pembelian secara online baik secara parsial maupun simultan. Jenis penelitian menggunakan pendekatan kuantitatif (explanatory research). Penelitian ini dilakukan pada pelanggan toko online Shoppe yang berjumlah sebanyak 118 responden. Teknik analisis data pada penelitian ini menggunakan analisis deskriptif dan regresi berganda. Hasil penelitian ini menunjukkan bahwa terdapat pengaruh yang signifikan pada variabel kegunaan, interaksi, estetika, dan bauran permasaran pada perilaku pembelian online baik secara parsial dan simultan. Hal tersebut menunjukkan bahwa generasi milenial yang membeli pada aplikasi shoppe merasa sangat mengetahui menggunakan aplikasi shopee dengan berbagai macam fiturnya dan hal tersebut sangat memengaruhi pada perilaku pembelian secara online.
\end{abstract}

Kata Kunci : Perilaku Pembelian, Generasi Milenial

\section{ABSTRACT}

Millennial generation is a generation that is very decisive in terms of internet usage. This generation is also the generation most purchased online which in the future will flourish. The purpose of this study is to study the interaction of usability, aesthetics, interaction, and marketing mix on online shopping behavior both partially and simultaneously. This type of research used quantitative. This research was conducted on customers of the online Shoppe store offered as many as 118 respondents. Data analysis techniques in this study used descriptive analysis and multiple regression. The results showed that there were significant effects on the variables of usability, interaction, aesthetics and permutation mix on online shopping behavior both partially and simultaneously. This shows that the millennial generation who buys on the shoppe application is very understanding using shopee applications with various kinds of conveniences and this greatly affects the online purchase.

\section{Keywords : Consumer Behavior, Millennial Generation}

\section{PENDAHULUAN}

Perkembangan teknologi saat ini mencapai pencapaian yang signifikan salah satunya yaitu maraknya tema revolusi industri 4.0 dan pengaplikasiaannya. Revolusi industri 4.0 menjadi salah satu acuan untuk meningkatkan efisiensi dan efektivitas termasuk dalam hal bisnis. Berbagai kegiatan saat ini dapat dilakukan dengan menggunakan teknologi seperti penggunaan dalam hal internet. Internet menjadi sebuah kebutuhan pada saat ini karena kegunaannya dalam mencari berbagai hal yang diinginkan, berbagi informasi, mengobrol, bekerja, belanja, permainan, dan sebagainya.

Perkembangan pengguna internet saat ini didominasi oleh generasi milenial. Indonesia dengan generasi milineal yang lahir pada tahun 1980-1999 (Krbova dan Tomas, 2015) menjadikan generasi yang dekat dengan teknologi (Constantinides, 2010; Lachman dan Deborah, 2013). Dapat dijelaskan bahwa generasi milenial terbiasa dengan menggunakan internet untuk kegiatan seharihari (San et al., 2015). Hasil survei yang dilakukan asosiasi penyelenggara jasa internet Indonesia 
(APJII) pada tahun 2016 menjelaskan bahwa sekitar 80\% atau sekitar 25 juta pengguna internet di Indonesia berusia 25-29 tahun dan sekitar 72\% pengguna berusia 30-34 Tahun. Dominasi pengguna internet tersebut merupakan kelahiran di era 1980-1999. Survei tersebut menunjukkan bahwa generasi milenial menjadi pengguna yang paling dominan dalam penggunaan internet (Kompas, 2016).

Hasil riset majalah Markerteers menjelaskan bahwa perilaku masyarakat Indonesia yang berbelanja di e-commerce atau online menjelaskan bahwa generasi milenial merupakan generasi yang paling banyak berbelanja di e-commerce (markerteers.com, 2018). Hal tersebut juga didukung hasil riset APJII yang menyatakan bahwa $11 \%$ pengguna internet di Indonesia mengakses internet untuk menjual atau membeli barang dan jasa melalui internet. APJII juga menjelaskan bahwa generasi milenial dianggap sebagai generasi yang paling banyak beraktivitas dalam belanja online di Indonesia (Kompas, 2016). Peran generasi milenial yang berbelanja melalui e-commerce tidak terlepas dari eratnya hubungan generasi milenial dengan teknologi digital.

Alasan generasi milenial membeli pada e-commerce ataupun secara online disebabkan oleh penggunaan yang mudah, mudah untuk berinteraksi, estetika, dan bauran pemasaran yang mudah (Constatinides, 2010; Petra, 2016). Penggunaan teknologi memudahkan para generasi milenial untuk mencari barang/jasa yang diinginkan. Konten pada e-commerce juga memiliki estetika yang menarik dan enak dipandang. Tata letak situs juga membantu dalam mencari atau memilih produk yang tepat saat berbelanja online. Pada konten e-commerce juga menyajikan tempat untuk berinteraksi dengan pengguna e-commerce lainnya dengan interaksi tersebut membuat lebih percaya dengan produk yang dijual di toko online.

Toko online juga menjelaskan informasi yang sangat jelas mulai dari pencarian produk/ jasa hingga pembayarannya. Hal tersebut sangat memudahkan pembeli untuk mencari produk yang diinginkan. Kondisi tersebut yang menjadi hal yang dipertimbangkan oleh generasi milenial dalam belanja di toko online (Constatinides, 2010). Perilaku belanja online menjadikan belanja online dapat dilakukan pada saat kapanpun, dimanapun, dan kondisi yang memungkinkan. Faktor harga juga sangat berpengaruh dalam belanja online, hingga ketersediaan macam-macam produk yang ditawarkan pada situs online. Adanya e-commerce diperlukan untuk mendapatkan pemahaman yang baik tentang faktor-faktor yang dapat memengaruhi perilaku pembelian online, bahkan dapat membantu marketing online untuk meningkatkan aplikasi mereka. Penggunaan website ataupun aplikasi dapat menunjukkan faktor-faktor terkait yang memenharuhi konsumen gen milenial ketika belanja online di situs belanja online tertentu.

Shoppe merupakan salah satu situs belanja online yang berkembang di Indonesia yang telah berhasil menarik konsumen Indonesia dalam satu tahun setelah pertama kali diluncurkan pada 2015 (Tribunbisnis, 2019). Upaya yang dilakukan oleh situs Shoppe untuk memasuki pasar belanja online Indonesia memperoleh penghargaan pemasaran 2017 sebagai kategori kampanye pemasaran terbaik (Tribunbisnis, 2019). Shopee merupakan perusahaan e-commerce yang berada di bawah naungan Garena (berubah nama menjadi SEA Group), merupakan perusahaan internet di Asia Tenggara. Shopee menjalankan bisnisnya dengan konsep Customer to Customer (C2C) yaitu sebuah konsep dengan menjual dari konsumen ke konsumen akhir. Shoppe menyediakan seperangkat aplikasi secara online untuk dapat memfasilitasi penjual dan konsumen paling akhir.

Shopee resmi diperkenalkan di Singapura pada tahun 2015 yang diikuti dengan negara Malaysia, Filipina, Taiwan, Thailand, Vietnam, dan Indonesia. Shoppe mengusung visi "Menjadi C2C Mobile Marketplace Nomor 1 di Asia Tenggara". Shopee pada saat ini berada di bawah naungan CEO, Chris Feng, pria lulusan terbaik dari Universitas Nasional Singapura yang memungkinkan para penggunanya membeli atau menjual barang melalui aplikasi yang tersedia di platform iOS dan Android.

Aplikasi Shoppe menunjukkan bahwa terdapat kegunaan, interaktivitas, dan estetika pada perilaku pembelian online generasi milenial pada aplikasi Shoppe. Penelitian Constatinides (2010) menjelaskan bahwa variabel kegunaan, interaktivitas, dan estetika berpengaruh pada perilaku pembelian secara online pada generasi milenial. Faktor-faktor tersebut yang dapat memengaruhi perilaku pembelian online generasi milenial secara bersamaan dan sebagian. Tujuan pada penelitian ini yaitu untuk mengetahui dan menjelaskan pengaruh secara parsial dan simultan dari 
variabel kegunaan, interaktivitas, estetika, dan bauran pemasaran terhadap perilaku pembelian secara online.

\section{TINJAUAN PUSTAKA}

\section{Penelitian Terdahulu}

Penelitian terdahulu merupakan bahan pendukung pada penelitian ini secara empiris. Berikut penelitian sejenis yang meneliti tentang generasi milenial dalam hal perilaku pembelian secara online. Pada penelitian Constantinides (2010) menyatakan bahwa sifat dasar perilaku konsumen online internet didasarkan oleh pengalaman pada belanja online. Pada penelitian Baeva (2011) menjelaskan bahwa konten web merupakan elemen yang spesifik memengaruhi sikap pelanggan terhadap belanja online dan membentuk niat yang lebih tinggi untuk membeli online, sedangkan dalam faktor yang berorientasi pelanggan, kepercayaan adalah elemen pengalaman web spesifik utama yang memengaruhi sikap pelanggan terhadap belanja online.

Penelitian Ariff, et., al (2013) menjelaskan bahwa terdapat lima faktor yang memengaruhi perilaku pembelian online yaitu kualitas informasi, pemenuhan/ keandalan/layanan pelanggan, Desain situs web, kecepatan web dan detail, serta privasi/keamanan. Uzun dan Poturak (2014) menjelaskan bahwa harga produk secara positif memengaruhi perilaku pembelian online. Konsumen yang membeli pada masa yang akan datang tidak dipengaruhi oleh desain web dan waktu pengiriman, namun pembelian yang akan datang konsumen dipengaruhi oleh pengalaman terakhir. Ada hubungan antara kepuasan konsumen dan niat mereka untuk membeli pada masa yang akan datang. Kepuasan konsumen dengan produk online dipengaruhi oleh kenyamanan produk dan kualitas yang ditawarkan. Penelitian ini menggunakan beberapa penelitian terdahulu sebagai acuan dan pendukung untuk mengembangkan penelitian dan menambah khasanah pada penelitian perilaku pembelian secara online.

\section{Kegunaan (Usability)}

Penggunaan web merupakan sebuah kemampuan untuk menemukan hal yang ingin dicari termasuk informasi dan kebutuhan dengan upaya yang minimal Constantinides (2010). Hal tersebut mencerminkan bahwa penggunaan web merujuk pada tingkat efisiensi dan efektivitas (Kühn et al., 2015). Pada konsep kegunaan web juga termasuk adanya elemen kemudahan dalam navigasi dan pencarian (Constantinides, 2010). Pada penggunaan web juga merancang kemudahan tentang tata letak dan navigasi mencari informasi secara online dan mengurangi kesulitan yang dihadapi konsumen pada saat berbelanja online (Hausman dan Siekpe dalam Adnan, 2014). Oleh karena itu, dapat disimpulkan bahwa kegunaan web merupakan kemudahan dan efektivitas dalam mencari hal yang diinginkan dengan kondisi yang minimal.

\section{Estetika (Estethic)}

Pada estetika menjadi indikator penting dalam penyediaan situs e-commerce terutama dalam hal kredibilitas penyedia belanja online (Constantinides, 2010). Daya tarik yang memikat pada situs web menjadi hal yang menarik bagi pelanggan (Uzun dan Poturak, 2014). Konsumen akan tertarik dengan situs yang memiliki tampilan kreatif dan profesional. Hal ini juga sebagai bukti bahwa situs tersebut dipercaya sehingga situs profesional harus membayar lebih untuk membuat tampilan yang menarik untuk situs webnya.

Adnan (2014) menjelaskan bahwa sangat penting bagi perusahaan untuk berinvestasi dalam kualitas situs web mereka untuk menarik dan mempertahankan pembeli online. Shergill dan Chen (2005) mengungkapkan bahwa kualitas desain situs web telah menjadi masalah penting dalam kepuasan pelanggan. "Perancang internet harus fokus pada penambahan fitur manusia seperti visual dan grafik yang menarik, model virtual 3 dimensi. Untuk menarik konsumen ke situs web mereka dan mendorong mereka untuk melakukan pembelian online. Constantinides (2010) mengidentifikasi komponen estetika yaitu desain web, kualitas presentasi, elemen desain, dan gaya/suasana.

\section{Interaksi (Interactivity)}

Interaksi pada situs web merupakan sebuah layanan yang dapat memfasilitasi pengguna internet dapat berkomunikasi dengan perusahaan maupun pengguna online lainnya (Constantinides, 
2010). Interaksi merupakan suatu kondisi yang sangat umum pada situs internet terutama saat berkonsultasi pada pembelian secara online (Li, 2014). Adnan (2014) menjelaskan bahwa dalam interasi terdapat dua unsur yaitu berinteraksi dengan perusahaan penyedia situs online maupun dengan pengguna online lainnya. Interaksi tersebut mencakup masalah yang dihadapi oleh konsumen, layanan purna jual, dan berbagi pengalaman saat berbelanja online. Layanan yang baik dapat menyebabkan kepuasan pada pelanggan sehingga menciptakan loyalitas pada situs web tersebut (Shergill dan Chen, 2005).

Penyediaan fitur interaksi memungkinkan pelanggan untuk menyesuaikan dengan kebutuhan mereka (Constantinides, 2010). Berdasarkan penjelasan tersebu, dapat disimpulkan bahwa dengan adanya interaksi dapat memudahkan berbagi pengalaman pada belanja online dan menyelesaikan masalah yang dihadapi oleh pelanggan belanja secara online.

\section{Bauran Pemasaran (Marketing Mix)}

Bauran pemasaran menjadi hal yang sangat memengaruhi proses pembelian online yang diikuti oleh pengaruh situasional yang mencakup waktu, uang, dan lingkungan sosial (Baeva, 2011). Constantinides (2010) menjelaskan bahwa bauran pemasaran (4P) termasuk pemenuhan adalah kontributor penting bagi pengalaman web. Peneliti terdahulu juga telah fokus pada efek bauran pemasaran terhadap perilaku pembelian online (Li, 2014). Constantinides (2010) juga telah mengidentifikasi komponen bauran pemasaran pada elemen pengalaman web yang terdiri dari: komunikasi, pemenuhan, produk, harga, dan promosi.

\section{Perilaku Belanja Online Generasi Milenial}

Istilah pembelian online atau belanja online telah digunakan untuk menggambarkan aktivitas saat berbelanja atau membeli melalui Internet. Bajpai dan Lee (2014) menyatakan bahwa "pembelian online adalah bagian dari perdagangan elektronik yang memungkinkan pelanggan untuk membeli produk dengan memanfaatkan layanan online melalui World Wide Web". Menurut Suki dan Suki (2013), belanja online tidak hanya membeli produk atau layanan, tetapi juga memungkinkan konsumen untuk mencari informasi melalui interaksi langsung dengan toko online.

Oleh karena itu, perilaku pembelian online didefinisikan sebagai aktivitas dalam mencari dan membeli barang atau jasa secara elektronik melalui internet melalui interaksi langsung dengan toko online. Konsumen melakukan belanja online tidak hanya untuk membeli produk secara online, tetapi juga untuk mendapatkan informasi seperti membandingkan harga, fitur produk, dan fasilitas layanan purna jual yang akan mereka terima jika mereka membeli produk dari toko online tertentu (Shergill dan Chen, 2005). Perilaku belanja konsumen di toko online berbeda dengan toko offline. "Belanja online telah dieliminasi di sisi konsumen seperti ketidaknyamanan belanja tradisional seperti melawan kerumunan, berdiri di antrean panjang, dan berjuang untuk ruang parkir di mal yang sibuk" (Suki dan Suki, 2013). Hasil penelitian Tabatabaei (2009) menunjukkan bahwa terdapat persepsi positif konsumen offline terhadap belanja online. Konsumen mungkin tertarik untuk melakukan belanja online untuk memenuhi kebutuhan dan keinginan mereka karena ada hal yang begitu efisien. Selain itu, belanja online menawarkan banyak kenyamanan bagi konsumen daripada belanja offline. Teknologi menjadikan generasi milenial mengandalkan media sosial sebagai tempat untuk mencari informasi termasuk dalam hal belanja online. The Nielsen Global Survey of E-commerce juga melakukan penelitian terhadap pergeseran perilaku belanja para generasi internet. Penelitian dilakukan berdasar penetrasi internet di beberapa negara (Republika, 2016). Studi tersebut menggambarkan perilaku generasi milenial akrab dengan jalur internet untuk memenuhi kebutuhan sehari-hari.

\section{METODE PENELITIAN \\ Rancangan Penelitian}

Berdasarkan tujuan penelitian yang ditetapkan, maka jenis penelitian ini dapat digolongkan sebagai penelitian penjelasan atau eksplanatori. Menurut Singarimbun (2006) yang dimaksud dengan penelitian penjelasan adalah penelitian yang menyoroti hubungan antara variabel-variabel penelitian dan menguji hipotesis yang telah dirumuskan sebelumnya. Penelitian penjelasan juga dinamakan penelitian pengujian hipotesis. Pada penelitian jenis ini, hipotesis yang telah dirumuskan akan diuji untuk mengetahui adanya hubungan dan pengaruh antara variabel- 
variabel dalam penelitian mengenai kegunaan, estetika, interaksi, dan marketing mix pada perilaku pembelian secara online pelanggan aplikasi belanja Shoppe.

\section{Lokasi dan Sampel Penelitian}

Penelitian ini dilakukan pada pelanggan online Shopee Indonesia. Peneliti menyebar kuesioner pada fans page shopee Indonesia pada sosial media seperti facebook, instagram, dan youtube. Fans page pada sosial media tersebut merupakan tempat untuk berbagi informasi terkait aplikasi Shopee Indonesia. Tempat tersebut menjadi tempat yang sangat mudah untuk mencari pelanggan setia Shopee dikarenakan mencari informasi produk, program diskon shopee, dan sebagainya. Alasan memilih media sosial tersebut juga dikarenakan mempertimbangkan kemudahan untuk bertemu pembeli online Shopee Indonesia terutama generasi milenial. Pada penelitian ini menggunakan 118 responden penelitian. Skala pengukuran yaitu dengan menggunakan skala Likert.

\section{Definisi Operasional Variabel}

Pada penelitian ini terdapat 2 variabel yaitu variabel independen dan variabel dependen. Variabel independen pada penelitian ini yaitu kegunaan (X1), estetika (X2), interaksi (X3), bauran pemasaran (X4). Variabel dependen pada penelitian ini yaitu perilaku pembelian online (Y). Merujuk pada Constantinides (2010) Kegunaan merupakan kemampuan untuk menemukan sesuatu yang dicari pada web kemudian mengetahui apa yang harus dilakukan selanjutan dengan melakukan upaya yang minimal. Indikator kegunaan pada penelitian ini yaitu kenyamanan, navigasi situs, arsitektur informasi, proses pemesanan atau pembayaran, fasilitas pencarian, kecepatan situs dan aksestabilitas.

Pada variabel Estetika (X2) menurut Constantinide (2010) merupakan sejauh mana pelanggan menemukan hal yang menarik dan memikat. Indikator pada estetika yaitu desain situs web, kualitas penyajian, elemen desain, dan gaya/suasana. Variabel interaksi (X3) menurut Constantinides (2010) merupakan penyediaan layanan yang dapat berinteraksi dengan pelanggan maupun pengguna online lainnya. Indikator yang digunakan yaitu layanan pelanggan, interaksi dengan personel perusahaan, kustomisasi, dan efek jaringan. Pada bauran pemasaran (X4) menurut Constantinide (2010) merupakan aspek pemasaran untuk dapat menarik pelanggan ke belanja. Indikator yang digunakan yaitu komunikasi, pemenuhan pemesanan, produk, harga, dan promosi. Variabel dependen pada penelitian ini yaitu perilaku pembelian secara online $(\mathrm{Y})$ yaitu aktivitas dalam mencari dan membeli barang/jasa secara elektronik melalui internet dengan indikatornya belanja online, perbandingan harga, dan ketersediaan produk yang luas.

\section{Teknik Analisis Data}

Tujuan dari penggunaan alat analisis data adalah untuk menyederhanakan data ke dalam bentuk yang lebih mudah untuk dibaca dan diinterpretasikan sesuai dengan tujuan penelitian yang telah ditetapkan, maka dalam penelitian ini menggunakan analisis deskriptif dan analisi regresi berganda yang dilengkapi dengan asumsi klasik.

\section{HASIL DAN PEMBAHASAN}

Data yang diperoleh pada penelitian ini berjumlah 118 responden yang merupakan pelanggan dari toko belanja online Shopee. Mayoritas responden pada penelitian ini adalah perempuan berjumlah 66 orang responden (55.9\%) dari 118 orang. Responden pada penelitian mayoritas berumur 27-31 tahun yang berjumlah 64 orang (54,2\%). Sarjana merupakan jenjang pendidikan mayoritas pada penelitian ini dengan jumlah 64 orang responden $(54,2 \%)$. Mayoritas responden membeli pada 1 bulan yang lalu dengan jumlah 51 responden $(43,2 \%)$. Produk pakaian merupakan mayoritas produk yang dibeli dengan jumlah responden 45 orang $(38,1 \%)$.

Pada penelitian ini menggunakan Analisis Regresi Berganda, sebelum menggunakan analisis tersebut harus terdapat uji asumsi klasik. Hasil uji klasik menyatakan bahwa analisis bisa memenuhi untuk menggunakan analisa regresi linier berganda.

\section{Analisis Regresi Berganda}

Berikut ini adalah hasil pengujian analisis regresi berganda yang terdapat variabel bebas dan variabel terikat. Varibel bebas pada penelitian ini yaitu kegunaan (X1), estetika (X2), interaksi 
(X3), dan bauran pemasaran (X4). Variabel terikat yaitu Perilaku belanja Online (Y). Berikut ini ringkasan hasil uji analisis regresi pada tabel 1,2, dan tabel 3.

Tabel 1. Hasil Pengujan Uji t (Parsial)

\begin{tabular}{cccccc}
\hline \multirow{2}{*}{ Model } & \multicolumn{2}{c}{ Unstandarized Coefficients } & $\begin{array}{c}\text { Standardized } \\
\text { Coefficients }\end{array}$ & \multirow{2}{*}{$\mathrm{t}$} & \multirow{2}{*}{ Sig. } \\
\cline { 2 - 4 } & $\mathrm{B}$ & Std. Error & Beta & & 0.266 \\
\hline 1 (Constant) & 0.282 & 1.058 & & 0.791 \\
\hline Kegunaan (X1) & 0.092 & 0.045 & 0.193 & 2.053 & 0.042 \\
\hline Estetika (X2) & 0.196 & 0.085 & 0.223 & 2.293 & 0.024 \\
\hline Interaksi (X3) & 0.082 & 0.035 & 0.233 & 2.387 & 0.019 \\
\hline Marketing Mix (X4) & 0.142 & 0.64 & 0.202 & 2.221 & 0.028 \\
\hline
\end{tabular}

a. Dependent Variable : Perilaku Belanja Online

Sumber: Data Diolah Penelitit (2018)

Tabel 2. Hasil Pengujan Uji F (Simultan)

\begin{tabular}{cccccc}
\hline Model & $\begin{array}{c}\text { Sum of } \\
\text { Squares }\end{array}$ & Df & $\begin{array}{c}\text { Mean } \\
\text { Square }\end{array}$ & F & Sig. \\
\hline Regression & 199.590 & 4 & 49.898 & 30.352 & $0.000^{\text {a }}$ \\
\cline { 1 - 4 } Residual & 185.766 & 113 & 1.644 & & \\
\cline { 1 - 4 } Total & 385.356 & 117 & & \\
\hline
\end{tabular}

a. Predictors : (Constant), Marketing Mix, Interaksi, Kegunaan, Estetika

b. Dependent Variable : Perilaku Belanja Online

Sumber: Data Diolah Peneliti (2018)

Tabel 3. Hasil Pengujan $R$ Square

\begin{tabular}{ccccc}
\hline Model & $\mathrm{R}$ & RSquare & $\begin{array}{c}\text { Adjusted R } \\
\text { Square }\end{array}$ & $\begin{array}{c}\text { Std. Error of The } \\
\text { Estimate }\end{array}$ \\
\hline 1 & 0.720 & 0.518 & 0.501 & 1.282 \\
\hline
\end{tabular}

a. Predictors : (Constant), Marketing Mix, Interaksi, Kegunaan, Estetika

Sumber: Data Diolah Peneliti (2018)

Tabel 1 menjelaskan tentang hasil uji t secara parsial diketahui persamaan regresi :

$\mathrm{Y}=0,282+0,193 \mathrm{X} 1+0,223 \mathrm{X} 2+0,233 \mathrm{X} 3+0,202 \mathrm{X} 4+1.058(\mathrm{e})$.

Pada tabel 2 menjelaskan tentang hasil uji secara simultan. Nilai $F_{\text {hitung }}$ sebesar 30,352. Nilai $F_{\text {tabel }}(\alpha=0.05 ; \mathrm{db}$ regresi $=4: \mathrm{db}$ residual $=113)$ adalah sebesar 1,968. Oleh karena $\mathrm{F}_{\text {hitung }}>$ $F_{\text {tabel }}$ yaitu $30,562>1,968$ atau nilai Sig. $F(0,000)<\alpha=0.05$ maka model analisis regresi secara simultan adalah signifikan. Hal ini berarti $\mathrm{H}_{0}$ ditolak dan $\mathrm{H}_{1}$ diterima sehingga dapat disimpulkan bahwa variabel terikat (perilaku belanja online) dapat dipengaruhi secara signifikan oleh variabel bebas yaitu kegunaan, estetika, interaksi, dan bauran pemasaran.

Pada tabel 3 menjelaskan besaran kontribusi menggunakan koefisien determinasi yang diperoleh pada nilai $\mathrm{R}_{\text {Square }}$ sebesar 0.518 . Nilai tersebut menjelaskan bahwa variabel bebas pada penelitian ini mempengaruhi variabel terikat yaitu perilaku belanja online yaitu sebesar $51,8 \%$, sedangkan sisanya 48,2\% dipengaruhi variabel lain yang tidak diteliti pada penelitian ini.

\section{Pembahasan}

Pengaruh secara simultan variabel bebas (Kegunaan, estetika, interaksi dan bauran pemasaran) pada Perilaku Pembelian Online.

Hasil penelitian ini menjelaskan bahwa variabel bebas kegunaan, estetika, interaksi, dan bauran pemasaran berpengaruh secara simultan dan signifikan terhadap perilaku belanja online. Hal tersebut mempunyai arti bahwa dengan menggunakan variabel tersebut para pelanggan Shopee telah sangat mudah dalam menggunakan aplikasi, estetika yang menarik, interaksi yang mudah dan bauran pemasaran yang dapat memudahkan dalam pembelian secara online. Hal ini sesuai 
dengan penelitian Constantinides (2010) bahwa perilaku belanja online ditentukan oleh variabel kegunaan, estetika, interaksi, dan bauran pemasaran. Para pelanggan Shoppe juga menjelaskan bahwa terdapat keuntungan ketika berbelanja online dengan melihat ketersediaan produk yang lebih luas.

Pengaruh secara parsial variabel bebas (kegunaan, estetika, interaksi dan bauran pemasaran) pada perilaku pembelian online.

\section{Pengaruh kegunaan $(\mathrm{X} 1)$ pada perilaku pembelian online $(\mathrm{Y})$}

Hasil penelitian ini menunjukkan bahwa variabel kegunaan berpengaruh pada perilaku belanja online pelanggan Shopee. Hal tersebut menunjukkan bahwa dengan kemampuan situs shoppe dapat efektif dan efisien dalam hal mencari produk yang diinginkan. Temuan tersebut konsisten dengan studi Constantinides (2010) yang menjelaskan bahwa kegunaan sebagai faktor yang memengaruhi perilaku pembelian online konsumen generasi milenial. Oleh karena itu, kegunaan memiliki pengaruh signifikan terhadap perilaku pembelian online generasi milenial yang terkait menyajikan kemudahan dan kegunaan saat berbelanja online di situs.

2. Pengaruh estetika (X3) pada perilaku pembelian online (Y)

Pada penelitian ini menunjukkan bahwa variabel estetika berpengaruh secara signifikan pada perilaku pembelian online. Hal tersebut menujukkan bahwa estetika yang menarik dengan tampilan visual yang memikat membuat pelanggan shopee merasa senang ketika berbelanja online. Persaingan di pasar online saat ini sangat ketat, sehingga tampilan dapat menjadi fokus oleh pemasar online untuk saling bersaing. Hal ini sejalan dengan penelitian yang dilakukan oleh Constantinides (2010) yang menjelaskan bahwa terdapat hubunga yang positif yang signifikan.

3. Pengaruh interaksi (X3) pada perilaku pembelian online $(\mathrm{Y})$

Pada penelitian ini menunjukkan bahwa pada variabel interaksi berpengaruh secara signifikan terhadap perilaku pembelian secara online. Hal tersebut menjelaskan bahwa dengan interaksi yang terdapat pada aplikasi shopee memudahkan para pembeli khususnya generasi milenial menghadirkan layanan yang lebih personal pada para pelanggan. Interaksi juga dapat diberikan dengan melihat komentar pelanggan lainnya terkait dengan pengalaman yang sudah terjadi. Hal tersebut sesuai dengan penelitian Constantinides (2010) bahwa interaksi dengan pengalaman menjadi unsur yang penting dalam pembelian online.

4. Pengaruh bauran pemasaran $(\mathrm{X} 4)$ pada perilaku pembelian online $(\mathrm{Y})$

Pada penelitian ini juga melihat bahwa aspek bauran pemasaran berpengaruh signifikan pada perilaku belanja online generasi milenial. Pengaruh tersebut menjelaskan bahwa promosi, harga, produk, dan kesan pada shopee sangat nyaman bagi konsumen generasi milenial pada shopee. Hal tesebut sesuai dengan penelitian Constantinides (2010) bahwa bauran pemasaran yang disediakan oleh Shopee id telah memengaruhi konsumen generasi milenial untuk berbelanja online di situs tersebut. Shopee id memiliki promosi yang menarik pada bauran pemasaran mereka, seperti sudut penawaran yang termasuk penawaran harian, penawaran mengejutkan, dan penawaran merek.

\section{KESIMPULAN DAN SARAN}

Penelitian ini mengetahui bahwa variabel kegunaan, estetika, interaksi dan bauran pemasaran berpengaruh secara signfikan baik secara parsial maupun simultan. Hal tersebut menjelaskan bahwa Shopee sangat serius dalam pembuatan konten untuk memudahkan para pelanggan berbelanja online dengan tampilan yang menarik, interaksi yang dilakukan dan bauran pemasaran yang terdapat pada Shopee. Penelitian berikutnya dapat mengkaji tentang kepercayaan dan resiko dalam berbelanja online hal tersebut dikarenakan menarik karena unsur jaminan pada berbelanja online penting untuk dipahami.

\section{DAFTAR PUSTAKA}

Adnan, Hooria. (2014). An Analysis of the Factors Affecting Online Purchasing Behavior of Pakistani Consumers. International Journal of Marketing Studies, Vol. 6, No. 5. Published by Canadian Centerof Science and Education. 
Ariff, Mohd Shoki Md, et al. (2013). Web-based Factors Affecting Online Purchasing Behaviour. IOP Conf. Series: Materials Science and Engineering. Published by IOP Publishing.

Baeva, Anelina Yasenova. (2011). Online Consumer Behavior: Web Experience Elements in Online Clothing Market. Master Thesis, Universidade de Coimbra.

Bajpai, Akansha and Dr. Cheng-Wen Lee. (2014). Online Buying Behavior: A Cross Country Study Between India and Taiwan. International Journal of Research in Finance \& Marketing, Volume 4, Issue 5.

Constantinides, Efthymios. (2010). Influencing the online consumer's behavior: the Web experience. Internet Research, Volume 14, Number 2, pp. 111-126. Published by Emerald Group Publishing Limited.

Ghozali, Imam. (2012). "Aplikasi Analisis Multivariate dengan Program IBM SPSS 20". Semarang : UNDIP.

Kompas, (2016). "Pengguna Internet di Indonesia Capai 132 Juta" https://tekno.kompas.com/read/2016/10/24/15064727/2016.pengguna.internet.di.indonesia.ca pai.132.juta.

Kühn, S.W, Spies and D.J. Petzer. 2015. Online servicescape dimensions as predictors of website trust in the South African domestic airline industry. Southern African Business Review. 19 (1): $44-71$

Krbová, Petra and Tomáš Pavelek. (2015). Generation Y: Online Shopping Behaviour of the Secondary School and University Students. Acta Universitatis Agriculturae et Silviculturae Mendelianae Brunensis, 63 (2): 567-575.

Lachman, m. Leanne., and Deborah 1. Brett. (2013). Generation Y: Shopping and Entertainment in the Digital Age. Washington, D.C: Urban Land Institute.

Li, Chenghuan. (2014). Factors influencing customers' choices of online Merchants. Master's thesis, Department of Information and Service Economy, Aalto University,School of Business.

Marketeers, (2018). “Trik Ampuh Garap Pasar Millennilas 2018' http://marketeers.com/menggarap-pasar-millennials-di-artpreneur-talk-2018/

Petra, Klapilová Krbová. (2016). Generation Y Attitudes towards Shopping: A Comparison of the Czech Republic and Slovakia. Journal of Competitiveness. Vol. 8, Issue 1, pp. $38-54$.

Republika, (2016). "2020, generasi milenial akan dominasi Indonesia". https://www.republika.co.id/berita/gaya-hidup/trend/16/03/04/o3hzva384-2020-generasimilenial-akan-dominasi-indonesia

San, Lim Ying., Azizah Omar, and Ramayah Thurasamy. 2015. Online Purchase: A Study of Generation Y in Malaysia. International Journal of Business and Management, Vol. 10, No. 6.

Shergill, Gurvinder S and Zhaobin Chen. (2005). Web Based-Shopping: Consumers' Attitudes towards Online Shopping in New Zealand. Journal of Electronic Commerce Research, Volume 6, No. 2.

Singarimbun, M dan Sofyan Effendi. (2006). Metode Penelitian Survei. Jakarta: LP3ES 
Jurnal Manajemen dan Bisnis MEDIA EKONOMI, Vol . XIX No 1 Januari 2019

Suki, Norazah Mohd and Norbayah Mohd Suki. (2013). Consumer Online Shopping Behavior: The Effect of Internet Marketing Environment, Product Characteristics, Familiarity and Confidence, and Promotional Offer. International Journal of Social, Education, Economics and Management Engineering, Volume 7 No. 3.

Tabatabaei, Manouchehr. (2009). Online Shopping Perceptions of Offline Shoppers. Georgia Southern University. Issues in Information Systems. Volume X, No. 2, 2009

Tribunbisnis, (2019). "kalahkan Tokopedia dan lazada, Shopee pimpin persaingan industri ecommerce asia tengaara di 2018. http://www.tribunnews.com/bisnis/2019/01/07/kalahkantokopedia-lazada-shopee-pimpin-persaingan-industri-e-commerce-asia-tenggara-di-2018

Uzun, Hana and Mersid Poturak. (2014). Factors Affecting Online Shopping Behavior of Consumers. European Journal of Social and Human Sciences, Vol.(3), No. 3. 